\title{
PLEODENDRON COSTARICENSE (CANELLACEAE), A NEW SPECIES FOR COSTA RICA
}

\author{
Barry E. Hammel ${ }^{1,2}$ and Nelson A. Zamora ${ }^{2,3}$ \\ ${ }^{1}$ Missouri Botanical Garden, P.O. Box 299, St. Louis, Missouri 63166, USA. \\ ${ }^{2}$ Instituto Nacional de Biodiversidad (INBio), apdo. 22-3100, Santo Domingo, Heredia, Costa Rica. \\ ${ }^{3}$ Organización para Estudios Tropicales (OET), apdo. 676-2050, San Pedro, Costa Rica.
}

\begin{abstract}
Pleodendron costaricense, a very rare, lowland rainforest tree known from southern Pacific Costa Rica is described and illustrated. Its only congener, P. macranthum, grows about $2000 \mathrm{~km}$ to the northeast, in Puerto Rico. The only other member of the family Canellaceae known from Central America is the mostly West Indian, Canella winterana, which reaches the Yucatan Peninsula of Mexico.
\end{abstract}

Resumen. Se describe e ilustra Pleodendron costaricense, una especie de árboles muy rara en el bosque lluvioso de bajura del Pacífico Sur de Costa Rica. La única otra especie congenérica, P. macranthum, se encuentra ca. $2000 \mathrm{~km}$ al nordeste, en Puerto Rico. Hasta ahora, la única especie de Canellaceae conocida en Centroamérica era Canella winterana, principalmente de las Antillas, que llega a la Península de Yucatán en México.

Key words / Palabras clave: Canellaceae, Pleodendron, Central America, Costa Rica, West Indies, disjunct

The new species of Pleodendron (Canellaceae) described below was discovered in Costa Rica just as the rediscovery of Takhtajania perrieri (Capuron) Baranova \& J.-F. Leroy (Winteraceae) in Madagascar was making news (e.g., Schatz et al. 1998, Schatz 2000). Though coincidental, these discoveries nevertheless merit mention together, their respective families being sister taxa (e.g., Karol et al. 2000) and among those often considered most closely related to (or least changed from), the earliest angiosperms. Such so-called living fossils always stimulate considerable interest; the study of their morphology, biology and ecology can give us insight into what the world was like millions of years ago.

The disjunct ocurrence of Pleodendron in Costa Rica and Puerto Rico adds another data point to our understanding of the complex biogeography of the region. But what kind of research program is most productive of such discoveries? In our view, general surveys, especially those coupled to a Flora project, can be more productive than efforts to find one specific item. Takhtajania perrieri was for many years the object of a concerted exploration of the type locality, but was only recollected as a result of a general botanical inventory of a different area (Schatz et al. 1998). Even that material might still lay incorrectly and tentatively determined (Schatz 2000) were it not for the stimulus provided through the Generic Tree Flora of Madagascar (Schatz 2001) project. The evidence of Pleodendron, coupled with numerous other examples from the Manual de Plantas de Costa Rica project, although anecdotal, clearly demonstrates the value of general surveys and flora projects in stimulating major discoveries (e.g., Zamora et al. 2004a). We challenge fund-raisers and grant reviewers, in the current theatre of difficult times, to reconsider the value of generalized research; the rewards are great, many, and unpredictable.

\section{Pleodendron costaricense $\mathbf{N}$. Zamora, Hammel \& R. Aguilar, sp. nova}

TyPe: Costa Rica; Puntarenas, cantón de Parrita, cuenca del Río Pirrís-Damas; Parrita, pie del Cerro Cabeza de Chancho, camino al Carmen, valle del Río Palo Seco, 300 m, 26 mar 2000 (fl), N. Zamora et al. 2986 (holotype: INB, isotypes: BH, CR, JBSD, K, MO, P, U, US). Fig. 1.

Differt a Pleodendro macrantho floribus multo minoribus, petalis circa dimidium brevioribus.

(It differs from $P$. macranthum by its much smaller flowers, the petals shorter by $c a .1 / 2$ ).

Tree, 15-35 m tall; external bark gray and white, weakly fissured and scaly; internal bark pale pink, aromatic; twigs pale gray, glabrous, lenticelate near apex, often with clusters of bud scale scars, presumably produced during periods of slow growth; terminal buds $9 \times 2 \mathrm{~mm}$, ovate-falcate, the young leaves convolutely folded and their margins minutely 
ciliate; stipules lacking. Leaves distichous; petiole 5$12 \mathrm{~mm}$ long, canaliculate above, articulate at the base; lamina 7-15.5 x 3.5-5.5 cm, oblong, basally obtuse to acute, sometimes weakly decurrent, apically acute to slightly acuminate, with an acumen to $7 \mathrm{~mm}$ long, glabrous on both surfaces, glossy above when dry, the midrib impressed above, raised below and turning reddish when dry, the major lateral veins $12-13$ pairs, the tertiary venation conspicuously reticulate on both sides, the margin entire and weakly revolute near the base when dry; numerous, clear, gland dots visible (most readily on upper surface) only with hand lens; flavor peppery hot. Flowers solitary, or in fasciculate clusters of 2-4 flowers, axillary or slightly supraaxillary, sometimes spread along leafless portions of twigs and there born axillary to \pm congested bud scale scars. Pedicels 2-5 mm long, often with numerous, spirally arranged, imbricate bracteoles, the lower ones $c a .0 .5 \mathrm{~mm}$, the distal ones $1-3 \mathrm{~mm}$, circular or semicircular. Floral buds globose, $c a .6$ x $6 \mathrm{~mm}$. Calyx cupular or campanulate, glabrous, 3-lobed, with a short tube $1-1.5 \mathrm{~mm}$, the lobes $1-1.5 \mathrm{~mm}$ long, rounded and slightly imbricate, minutely ciliate. Petals 12 , free, apically obtuse to rounded, glabrous, in three distinct series, the outer 3 petals $5-7 \times 3.5-4.5 \mathrm{~mm}$, ovate, succulent (1.3-1.5 mm thick), the next 3 petals $5-7 x$ 1.6-2.5 mm, lanceolate, succulent (1.0-1.3 mm thick), the innermost 6 petals \pm equal, $3.7-5.3 \times 1.5-2 \mathrm{~mm}$, elliptic, \pm membranaceous (c. $0.5 \mathrm{~mm}$ thick), basally valvate, apically irregularly imbricate, internally faintly striate by the impression of the androecium. Androecium of connate stamens, a staminal column surrounding the ovary, the lower portion 3-5 mm long, the upper portion comprised of $c a$. 24, bisporangiate, longitudinally and extrorsely dehiscent thecae, 1.5-2 $\mathrm{mm}$ long, the thecae sessile and dorsally adnate to the staminal column (as the ovary develops, the staminal column appears to split longitudinally and detach circumscissiley at the base). Ovary $4.5-4.8 \times 2.3 \mathrm{~mm}$, bottle-shaped, glabrous, unilocular, the placentation parietal with $c a$. 6 rows of paired ovules, the ovules numerous, reniform; stigma capitate, $c a$. 6-lobed. Fruit a berry, $2.5 \times 3 \mathrm{~cm}$, oblate, green, smooth, and slightly glaucous; seeds many, 4-5 x $4 \mathrm{~mm}$, ovate to oblong or somewhat reniform, black, shiney, the funicular scar impressed and rounded; endosperm not ruminate.

Paratypes: COSTA RICA. Puntarenas: Cantón de Osa, Península de Osa, Rancho Quemado, camino a Chiquerón, 200 m, 15 ago 1998 (fr), R. Aguilar 5509 (INB); 30 jul 1999 (fr), R. Aguilar 5705 (CR, F, INB, MO, NY, P, UPR, US); 11 febr 2000 (fl), R. Aguilar
5934 (INB, CR, K, MO, U, US); Cantón de Parrita, cuenca del Río Pirrís-Damas; Parrita, pie del Cerro Cabeza de Chancho, camino al Carmen, valle del Río Palo Seco, 300 m, 26 febr 2000 (fl), R. Aguilar 6007 (CR, G, HULE, INB); 7 febr 2000 (fl), B. Hammel 22049 (BH, BM, CR, JVR, INB, K, MEXU, MO, NO, NY, P, PMA, QCA, QCNE, SPF, TEX, UPR, US), 21 febr 2000 (fl), B. Hammel 22063 (CAS, COL, CR, EAP, F, INB, MICH, MO, US, USJ), 3 jul 2003 (fl, fr.), J. Salazar et al. 2622 (BH, JBSD). San José: Cantón de Tarrazú, Zona Protectora Cerro Nara, cuenca del Río Naranjo y Paquita, faldas del Cerro Nara, bosques arriba de Quebrada Salitrillo, junto al camino, $250 \mathrm{~m}$, 18 mar 1999 (sterile), A. Rodríguez \& V. Ramírez 4682 (INB, CR, MO).

History of DISCOVERy. Given the combined expertise of botanists in Costa Rican along with the essentially instant and global collaboration possible through the Internet, any fertile, native plant that we can't immediately place to family is motive for much excitement. When this plant first came to our attention, sometime after August 1998, having only a rather meager collection with fruits, we remained puzzled by it for several months, and anxiously awaited the appearance of better material, especially flowers, for more than a year. Our ephemeral conjectures included such families as Annonaceae, Capparaceae, Ebenaceae. This large, lowland rainforest tree, with Annona- or Diospyros-like leaves, but with baccate fruits with numerous, small, black seeds, had us all stumped. As time wore on, our determination to get to the bottom of the mystery grew. In an evening of carefully examining, dissecting, squeezing, and sniffing the specimens, generally of highly animated consultation among numerous botanists then present at the Instituto Nacional de Biodiversidad (INBio), a strong smell memory - that of the fruits and seeds of Virola (Myristicaceae) - came to us on crushing the seeds of our mystery plant. Although all Costa Rican Myristicaceae have fruits with a single, large seed, we opened Cronquist (1981) to see if some odd, South American genus might fit our plant. More than anything else it was our quirky smell memory, and Cronquist's treatment of Canellaceae as closely related (and described on the immediately subsequent page) to Myristicaceae, that got us on track. The description of Canellaceae fit our plant to a tee, and the thrill was tangible. Leaf material sent for DNA analysis to a colleague working on the phylogeny of the early angiosperms placed our plant squarely within Canellaceae (Elizabeth Zimmers, pers. com.). 
And finally, flowering material, gathered more than a year after the original collection, also confirmed our identification.

Why, one might now ask, did it take us so long, to figure out the family of this plant? First, it wasn't really very long, by "Takhtajanian" standards; the first collection of Takhtajania perrieri remained without definite placement as to family, as well as undescribed, for 54 years (Schatz 2000). More to the point, however, is the tautological observation that we can't know what we don't know. Canellaceae had never been found in Costa Rica, are known from Mesoamerica - and there, essentially only from the Yucatan of Mexico - only by one species, Canella winterana (L.) Gaertn., none of us trying to figure out the mystery hardly remembered having heard of the family, let alone had ever had direct experience with it, and we hadn't yet invited our "Internet" colleagues into the search. Thus, in retrospect, we came to a solution of our mystery as quickly as we did, in part because of experience, and in part, as is often the case with such matters, because of luck.

Phenology. Flowering material of Pleodendron costaricense has been collected in February and March. Not all flowers open at the same time; anthesis occurs as a successive process. We also noted that in a particular season, some branches apparently did not flower at all. The fully mature flowers (Figs. $2 \& 3$, C), remain globose, the petals \pm erect and spreading to only a small, circular opening. Fruits are nearly mature by late July and last into August.

Morphology, Relationships \& Biogeography. This species is recognized as belonging to the Canellaceae by virtue of its alternate, entire, exstipulate, coriaceous, aromatic leaves, and flowers with three sepals, stamens connate into a staminal column with extrorse anthers, and an ovary with parietal placentation that in fruit is a berry.

Two (Canella and Warburgia) of the six genera of Canellaceae have consistently five-merous corollas and androecia (e.g., Tieghem 1899, Wilson 1966). In addition Warburgia is five-carpellate. Cinnamodendron and Cinnamosma are variable in merosity of corolla, androecium and ovary (e.g., Schatz 2001, Wilson 1966). Canella has two carpels, and Cinnamodendron has 2-4 carpels (J. Salazar, pers. com.). Capsicodendron (Occioni 1943) and Pleodendron have three-merous corollas and ovaries. The petals of Canella are basally connate and Cinnamosma has a salverform corolla. All other genera have free petals. Pleodendron ekmanii Urb. was described from sterile material from Haiti, but preliminary evidence indicates that it is more likely conspecific with one of the species of Cinnamodendron known from the Greater Antilles (J. Salazar, pers. com). Pleodendron macranthum (Baill.) Tiegh. has been interpreted as having 11 or 12 petals in four "false" (Baillon 1882) series of three petals each, or more decidedly as 12 petals disposed in four alternate verticels (Tieghem 1899, Little et al. 1988). In his comparative study of the floral morphology of the genera of Canellaceae, Wilson (1966: 340) found P. macranthum's 12 petals to be in just two series of six, each with an apparent "alternation of large and small petals." Thus, Pleodendron has essentially three-merous flowers throughout ( 3 sepals, 12 petals, 24 bisporangiate thecae, 6 carpels; see Table 1).

Thus considered, the only sure floral differences between the two known species of Pleodendron, $P$. macranthum, and $P$. costaricense, are the much smaller peduncles and petals in the latter (less than $1 / 2$ as long as those of $P$. macranthum). The fruits of the two are also quite different (see Fig. 3, D \& E). Other possible floral differences are subject to interpretation, e.g., in mature flowers of $P$. costaricense we see three series $(3+3+6)$ of petals (Fig. 1, H), the outer two thicker than the inner one, whereas $P$. macranthum has been interpreted to have four $(3+3+3+3)$ or two $(6+6)$ series. Nevertheless, the transverse sections through the median part of a flower of P. macranthum (Wilson 1966: 338, Fig. 16) and P. costaricense (Fig. 1, H) are very similar.

Besides P. costaricense, the only other member of the Canellaceae that occurs in Central America is the relatively widespread, mostly West Indian Canella winterana, which reaches the Yucatan Peninsula of Mexico. Otherwise, this family of only about 15 species is known from southern Florida (Canella), the West Indies (Canella, Cinnamodendron, Pleodendron), northeastern South America (Canella, Cinnamodendron), southeastern Brazil (Capsicodendron, Cinnamodendron), southeastern Africa (Warburgia), and Madagascar (Cinnamosma). Pleodendron costaricense, apparently typical for most New World members of the family (e.g., Zanoni 2004), is of very local distribution, so far known from only two, rather distant sites, along the southern pacific coast of Costa Rica, at 200-300 m elevation. The species itself is disjunct by about 2000 $\mathrm{km}$ from its presumed phylogenetically closest rela- 
tive, Pleodendron macranthum (Puerto Rico).

The fossil record of the Canellaceae is insufficient to reveal much about its biogeographic history, but two genera have been recognized in Tertiary deposits of Latin America. Hollick and Berry (1924) describe leaves of Canella from beds estimated as Pliocene in age from Bahia, Brazil, and Graham and Jarzen (1969) report pollen of Pleodendron from the middle Oligocene of Puerto Rico.

Although apparently rare, a possible phytogeographic relation between southern Costa Rica (or southern Central America) and the Caribbean is demonstrated by several species (in other families) that we know to be disjunct between Costa Rica and the West Indies, e.g., Pera oppositifolia Griseb. (Euphorbiaceae), Ziziphus chloroxylon (L.) Oliv. (Rhamnaceae), and Freziera grisebachii Krug \& Urb. (Theaceae). If we were also to include taxa such as Colpothrinax and Acoelorraphe wrightii (Griseb. \& H. Wendl.) H. Wendl. ex Becc. (Arecaceae) that are endemic to the Mesoamerican/Caribbean region, the list would certainly be much larger. Fournier (1966), Gómez P. (1986), and Zamora et al. (2004b) also mention this phytogeographic relationship. Within Mesoamerica, recent general floristic work has uncovered Costa Rican species of Nyssa and Tetranema disjunct with their geographically nearest congeners in Mexico and Honduras, respectively, as well as species of Amelanchier, Bakeridesia, Bouvardia, Chiangiodendron, Deherainia, Gymnosporia, Hintonia, Maytenus, Oecopetalum, and Reccia that are disjunct from as far north as Mexico, and no closer than Belize (Zamora et al. 2004a). Rather than a direct relationship with South America, as is especially common with species of the wet lowlands of southern Central America, such species as Pleodendron costaricense seem to have arrived via a much more complex, northern route.

Within the Canellales (Canellaceae + Winteraceae), the widespread, Neotropical Drimys granadensis L.f. (Winteraceae) is $P$. costaricense's geographically closest relative. It can be found as close as $1000 \mathrm{~m}$ upslope and a few $\mathrm{km}$ to the east of the $P$. costaricense localities, but probably got there by a much different route, via the ancient, Southern Hemisphere temperate forests (e.g., Berry et al. 2004). The discovery of Pleodendron costaricense is another data point supporting the growing conclusion (e.g., Burnham \& Graham 1999, Wendt 1993) that the forests of Central
America have a more complex origin than previously thought.

Habitat, Distribution and CONSERVATION. We know of only two mature individuals and one sapling of this species, in the wild. All occur on the Pacific lowlands of southern Costa Rica, in tropical wet forest formation (Tosi 1969), on well-drained soils with red clays. Although both mature individuals produce abundant fruits with seed, we have found only one seedling and have not been able to germinate any seeds. Both of these individuals occur at the edge of roads; the Parrita plant along a much-traveled gravel road, recently improved to provide access to a hydroelectric project, and the Osa plant along a more or less abandoned logging trail (Fig. 3, A \& B). None of these individuals occurs on land with a governmental conservation category that prohibits logging.

To say that Pleodendron costaricense is rare and endangered is almost an understatement; the formal IUCN Red List rating of this species calculates to be, unambiguously, Critically Endangered (CR D). Although the mature individuals hardly seem reproductively viable, the one known sapling from the Cerro Nara area, and the one we have nurtured from the single seedling encountered, do insert a minor note of hope.

Far too rare to have any known economic use, Pleodendron costaricense nevertheless merits all possible effort to bring it back from the verge of extinction. It is a living dinosaur that harbours information about the history of the Earth; its tenuous hold at the edge of roads should make it a poster-child for campaigns to save the biogeographic libraries that such species and the forests around them represent. Some members of the Canellaceae are locally well known in other parts of the world, and especially because of their aromatic essential oils, have been used for condiment, tonic, stimulants, incense, and herbal medicine [e.g., Canella winterana - Canella bark, Cinnamodendron corticosum Miers - False Winter's bark, Cinnamosma fragrans Baill. - Saro oil, Warburgia sartoris (Bertol. f.) Chiov. - Pepper bark]. Human nature leads common folk the world over always to ask "what's it used for?" and to assume (formerly to esteem, now more often to suspect) the work of a field botanist as equivalent to "looking for medicines." Sometimes we scientists are caught up in such efforts, witness the recent and passing wave of bioprospecting, but what really drives us is this thrill 
of discovery. During the last 15 years, in the course of a general botanical inventory of Costa Rica, aimed, in part, at the production of a modern flora of the country, we have recorded nearly 1000 new species or country records, numerous of them representing significant disjuncts from their previous known ranges or closest relatives (see Zamora et al. 2004a for a more complete account, and e.g., Grayum \& Hammel 1995, Hammel \& Zamora 1990, 1993, for specific examples). Although some are more exciting than others, every single species found new, or recorded new distribution, is full of related bytes of information about the history of life; that is what motivates our science.

Acknowledgments. We thank illustrator Silvia Troyo for her interpretation of this species; her fine drawing essentially obviates the 452 words (of detailed description) that supplement it. We thank George Schatz and Jackeline Salazar for comments on an early draft of this paper, and the latter also for providing us with much helpful information on Canellaceae, and for the use of her photo of the fruits of Pleodendron macranthum. We also thank Alan Graham for helpful suggestions concerning biogeography and paleobotany of Canellaceae. This research was possible due to cooperation agreement between Ministerio de Ambiente y Energía (MINAE) and Instituto Nacional de Biodiversidad (INBio), economic support from donors and the network of taxonomists that contribute to complete the national biodiversity inventory of Costa Rica.

\section{Literature Cited}

Baillon, M. 1882. Un nouveau Cinnamodendron. Bull. Mens. Soc. Linn. Paris 1: 317-319.

Berry, P.E., W.J. Hahn, K.J. Sytsma, J.C. Hall \& A. Mast. 2004. Phylogenetic relationships and biogeography of Fuchsia (Onagraceae) based on noncoding nuclear and chloroplast DNA data. Amer. J. Bot. 91: 601-614.

Burnham, R.J. \& A. Graham. 1999. The history of neotropical vegetation: new developments and status. Ann. Missouri Bot. Gard. 86: 546-589.

Cronquist, A. 1981. An integrated system of classification of flowering plants. Columbia Univ. Press, New York.

Fournier O., L.A. 1966. Botany of Cocos Island, Costa Rica. In: Bowman, R.I. (ed.). The Galapagos: Proceedings of the Symposium of the Galapagos International Scientific Project. Univ. Calif. Press, Berkeley. p. 183-186.
Gómez P., L.D. 1986. Vegetación de Costa Rica. In: Gómez P., L. D. (ed.). Vegetación y clima de Costa Rica. Vol. 1. Edit. UNED, San José.

Graham,A. \& D.M. Jarzen. 1969. Studies in neotropical paleobotany. I. The Oligocene communities of Puerto Rico. Ann. Missouri Bot. Gard. 56: 308357.

Grayum, M.H. \& B.E. Hammel. 1995. The genus Tetranema (Scrophulariaceae) in Costa Rica with two new species. Phytologia 79: 276-279.

Hammel, B.E. \& N.A. Zamora. 1990. Nyssa talamancana (Cornaceae), an addition to the remnant Laurasian Tertiary flora of southern Central America. Brittonia 42: 165-170.

\& ___. 1993. Ruptiliocarpon (Lepidobotryaceae): a new arborescent genus and tropical American link to Africa, with a reconsideration of the family. Novon 3: 408-417.

Hollick, A. \& E.W. Berry. 1924. A late Tertiary flora from Bahia, Brazil. Johns Hopkins Univ. Studies Geol. 5: 1-136.

Karol, K.G., Y. Suh, G.E. Schatz \& E.A. Zimmer. 2000. Molecular evidence for the phylogenetic position of Takhtajania in the Winteraceae: inference from nuclear ribosomal and chloroplast gene spacer sequences. Ann. Missouri Bot. Gard. 87: 414-432.

Little, Jr., E.L. 2000. Árboles de Puerto Rico y las Islas Vírgenes. U.S. Dept. Agriculture. Agriculture Handbook No. 449-S.

Occhioni, P. 1943. Sôbre a nomenclatura de uma espécie da família "Canellaceae". Rev. Brasil Biol. 3: 481-486.

Schatz, G.E. 2000. The rediscovery of a Malagasy endemic: Takhtajania perrieri (Winteraceae). Ann. Missouri Bot. Gard. 87: 297-302.

2001. Generic Tree Flora of Madagascar. The Cromwell Press, St. Louis.

P.P. Lowry \& A. Ramisamihantanirina. 1998. Takhtajania perrieri rediscovered. Nature 391: 133134.

Tieghem, P. van. 1899. Sur les Canellacées. J. Bot. (Morot) 13: 266-276.

Tosi, J.A., Jr. 1969. Mapa ecológico, República de Costa Rica; según la clasificación de zonas de vida del mundo de L.R. Holdridge. Centro Científico Tropical, San José.

Wendt, T. 1993. Composition, floristic affinities, and origins of the canopy tree flora of the Mexican Atlantic slope rain forests. In: Ramamoorthy, T.P., R. Bye, A. Lot \& J. Fa (eds.). Biological Diversity of Mexico, Origins and Distribution. Oxford Univ. Press, New York. p. 595-680. 


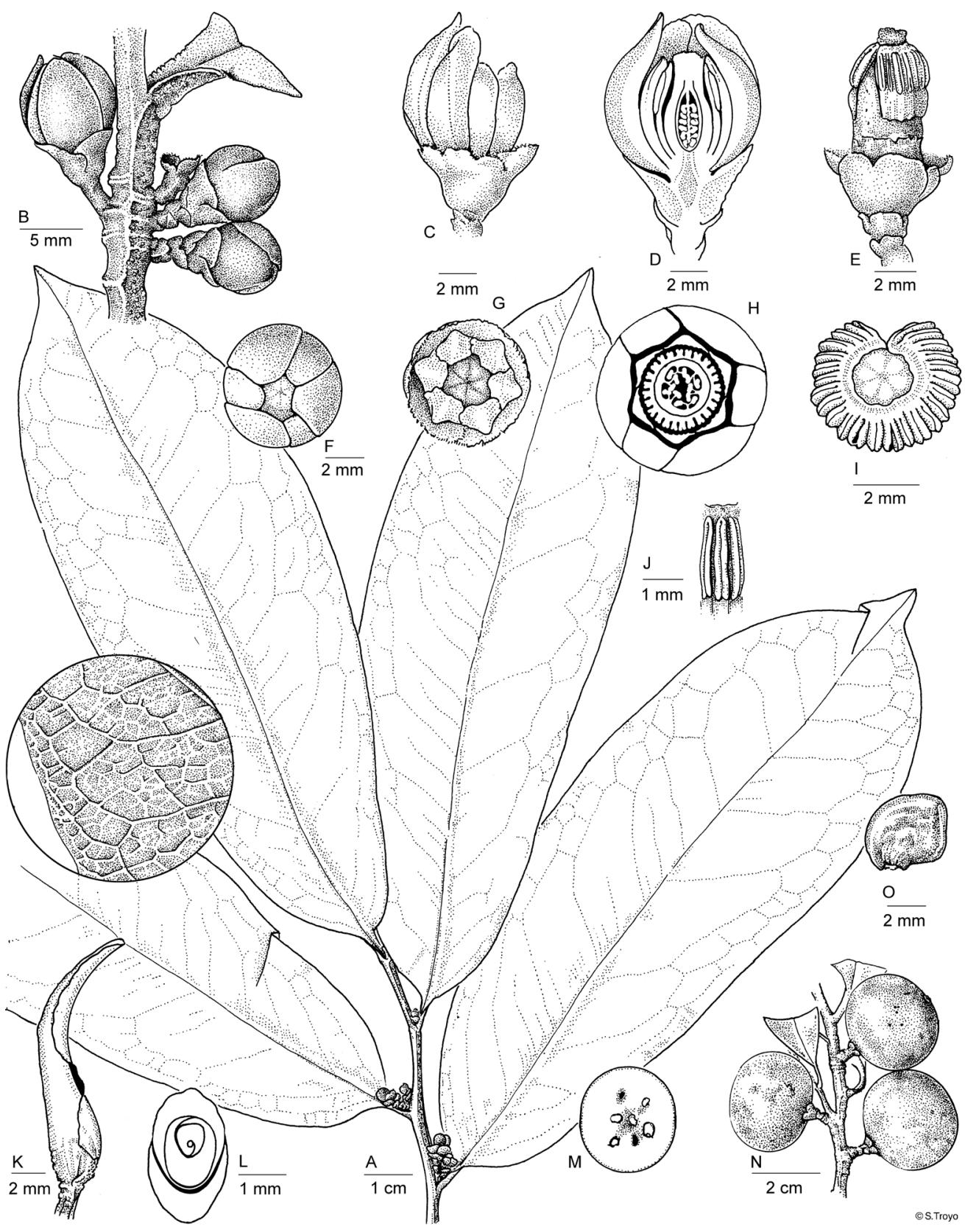

Fig. 1. Pleodendron costaricense N. Zamora, Hammel \& R. Aguilar. -A. Branch with flower buds. -B. Nearly mature flower and buds on stem below leaf. -C. Lateral view of flower with four petals removed, showing one of the first series and second series, and two of the third. -D. Median longitudinal section of flower. -E. Lateral view of flower with all petals removed showing split and circumscissile androecium. -F. Top view of mature flower. -G. Top view of flower with outer two series of petals removed. -H. Median transverse section of flower. -I. Top view of androecium and stigma. -J. Lateral view of three thecae. -K. Terminal bud. -L. Transverse section of terminal bud. -M. Median transverse section of fruit. -N. Branch with fruits. -O. Seed. (A-L from the type, Zamora et al. 2986; M-O from Aguilar 5705.). 
Wilson, T.K. 1966. The comparative morphology of the Canellaceae. IV. Floral morphology and conclusions. Amer. J. Bot. 53: 336-343.

Zamora, N., B.E. Hammel \& M.H. Grayum. 2004a. Novelties. In: Hammel, B.E., M.H. Grayum, C. Herrera \& N. Zamora (eds.), Manual de plantas de Costa Rica. Vol. I. Introducción. Monogr. Syst. Bot. Missouri Bot. Gard. 97: 217-240.

$$
\text { , \& ___ 2004b. Vegetation. In: }
$$

Hammel, B.E., M.H. Grayum, C. Herrera \& N. Zamora (eds.). Manual de plantas de Costa Rica. Vol. I. Introducción. Monogr. Syst. Bot. Missouri Bot. Gard. 97: 91-216.

Zanoni, T.A. 2004. Canellaceae. In: Smith, N., S.A. Mori, A. Henderson, D.W. Stevenson \& S.V. Heald (eds.). Flowering Plants of the Neotropics. Princeton Univ. Press, Princeton. p. 81.

Table 1. Summary of distinguishing floral characters of genera of Canellaceae, and of Pleodendron costaricense. Data compiled from Baillon (1882), Little et al. (1988), Occioni (1943), J. Salazar (pers. com.), Schatz (2001), Tieghem (1899), Wilson (1966).

\begin{tabular}{|l|c|c|c|c|c|}
\hline & No. Petals & $\begin{array}{c}\text { No. of Series } \\
\text { of Petals }\end{array}$ & Fusion of Petals & No. of Thecae & No. of Carpels \\
\hline Canella & 5 & 1 & basally connate & 20 & 2 \\
\hline Capsicodendron & 6 or 8 & 2 & free & $12--20$ & 3 \\
\hline Cinnamodendron & 6 or 10 & 2 & free & $14--20$ & $2--4$ \\
\hline Cinnamosma & $3--6$ & 1 & $\begin{array}{c}\text { connate (corolla } \\
\text { salverform) }\end{array}$ & $14--20$ & $3--5$ \\
\hline Pleodendron macranthum & 12 & $4(2)$ & free & 24 & 6 \\
\hline Pleodendron costaricense & 12 & $3(2)$ & free & 24 & 6 \\
\hline Warburgia & 10 & 2 & free & 20 & 5 \\
\hline
\end{tabular}

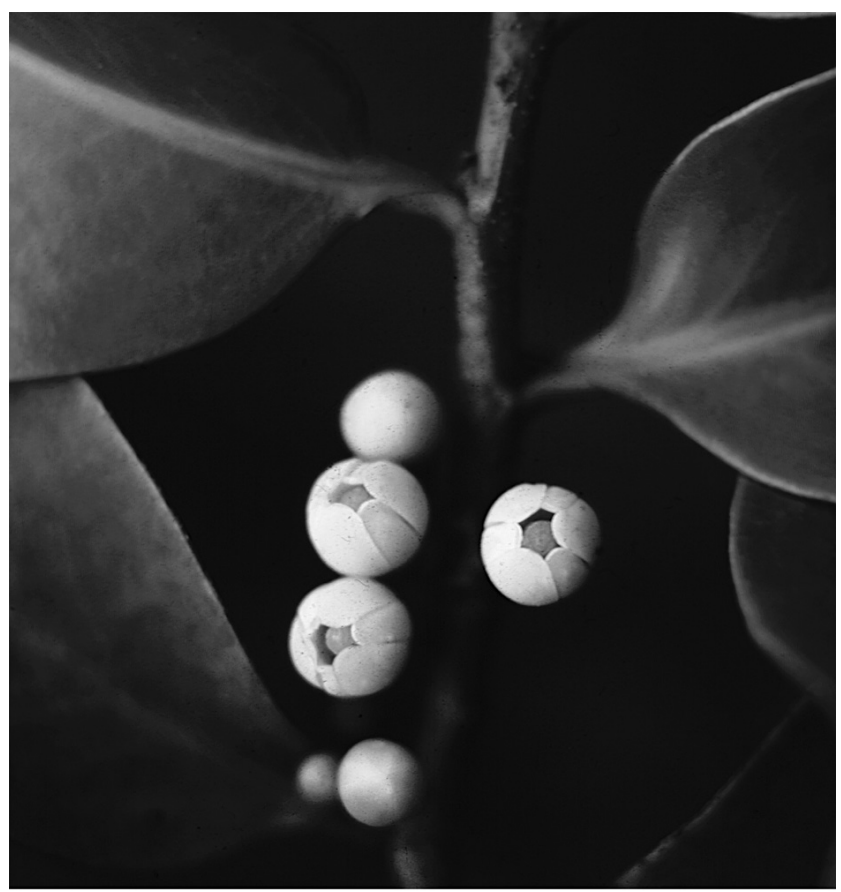

Fig. 2. Pleodendron costaricense N. Zamora, Hammel \& R. Aguilar. Branch with mature flowers seen from above. (Photo from type gathering, Zamora et al. 2986, by R. Aguilar.) 


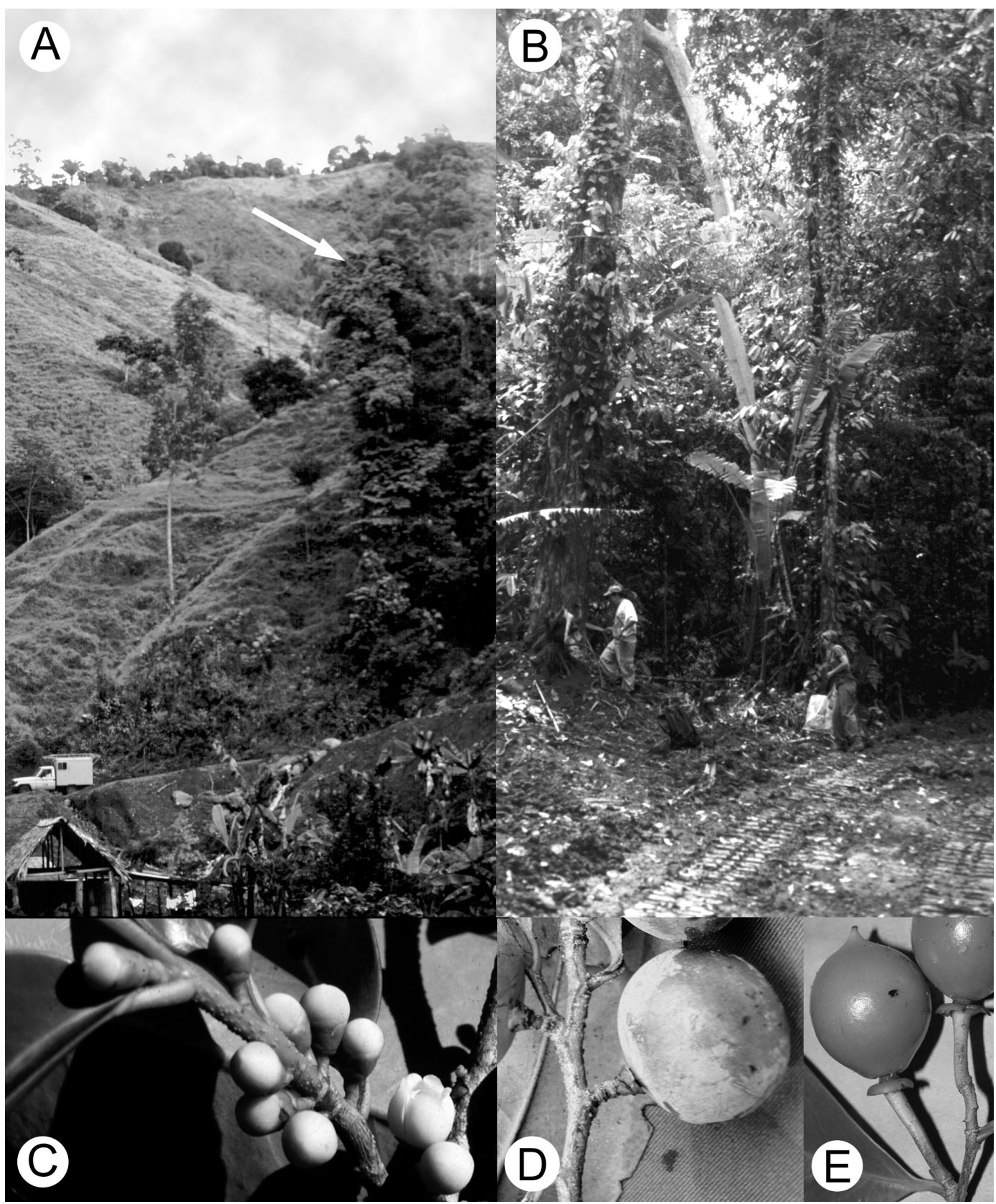

Fig. 3. A-D, Pleodendron costaricense N. Zamora, Hammel \& R. Aguilar. -A. Parrita locality and individual (arrow). -B. Osa locality and individual (trunk in front of R. Aguilar, person on left; other person is L. Bohs). -C. Branch with flower buds and open flower. -D. Fruiting branch. -E. Pleodendron macranthum (Baill.) Tiegh. Fruiting branch (Salazar et al. 2409; BH, JBSD). 